\title{
A Genetic Perspective on Nutritional Profiles: Do We Still Need Them?
}

\author{
Dario Gregori $^{\mathrm{a}}$ Francesca Foltran $^{\mathrm{a}}$ Elvira Verduci ${ }^{\mathrm{b}}$ \\ Simonetta Ballali ${ }^{a}$ Laura Franchin ${ }^{c}$ Marco Ghidina ${ }^{c}$ \\ Georges M. Halpern ${ }^{d}$ Marcello Giovannini ${ }^{b}$ \\ a Laboratories of Epidemiological Methods and Biostatistics, Department of \\ Environmental Medicine and Public Health, University of Padua, Padua, ${ }^{b}$ Department of \\ Paediatrics, San Paolo Hospital and University of Milan, Milan, and ' $\mathrm{C}$ Data Management, \\ ZETA Research Srl, Trieste, Italy; ${ }^{d}$ Department of Applied Biology and Chemical Technology, \\ Hong Kong Polytechnic University, Hong Kong, China
}

\section{Key Words}

Nutrient profiling $\cdot$ Nutrigenetic assessment $\cdot$ Nutritional counselling

\begin{abstract}
Background: The emergence of nutritional genomics and the availability of nutrigenetic tests, which use genetic information to identify food products suited/not suited to the individual nutrigenetic profile, allow defining personalized dietary advice. Aim: To compare personalized dietary advice provided to 24 Italian children by a nutrigenetic test based on the recommendations from 2 different, widely employed nutrient profiling (NP) schemes, the USA Health Claims (USAHC) and the Guidelines for Responsible Food Marketing to Children, published by the US Center for Science in the Public Interest (CSPI); the genetic test-NP agreement regarding 50 commonly eaten foods has been calculated. Methods: Twelve normal-weight and 12 overweight children were recruited in the Trieste district (North-East Italy), and nutrigenetic testing was offered using the G-Diet ${ }^{\circledR}$ Nutrigenomic Kit. Variants of 20 genes were tested and personalized dietary advice was formulated for each subject. The agreement between the NP schemes and among the nutrigenomic indications and both profiles was computed using Cohen's $\kappa$. Results: Agreement between the USAHC and CSPI schemes was very poor overall (Cohen's $\kappa=0.66$ ). The agreement among the nutrigenomic indications and profiles ranged overall from 0.43 to 0.74 for each nutrigenomic profile with the USAHC, and from 0.29 to 0.80 with the CSPI. Conclusion: Disagreement on food classification among different NP schemes and inconsistencies deriving from nutrigenetic tests advocate more research into this area.




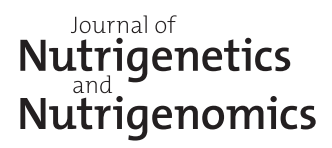

J Nutrigenet Nutrigenomics 2011;4:25-35

DOI: $10.1159 / 000322569$

Published online: March 23, 2011

Gregori et al.: Genetic Perspective on NP
(C) 2011 S. Karger AG, Basel www.karger.com/jnn

\section{Introduction}

Food has been identified as one of the most important environmental factors having a life-long impact on human health; therefore, modern nutritional research focuses on preventing or delaying the onset of chronic morbid conditions, widely recognized as influenced by dietary choices [1]. Focusing on prevention is of key importance in childhood, given the increasing prevalence of obesity, overweight, diabetes and cardiovascular diseases in paediatric populations [2]. At the present, public health efforts are mainly finalized to promote a 'healthy diet', encouraging informed and healthy food choice by the consumer. Accordingly, several health authorities and regulatory bodies are assessing the nutritional composition of food items to implement guidelines aimed at improving the diet of the general population [3]. Therefore, nutrient profiling (NP), which has been defined as 'the science of categorising foods according to their nutritional composition' [4, 5], has been developed, and so far several NP schemes have been proposed for varied purposes including regulating health claims, guiding consumers' choices and providing a rationale for food taxation [6].

However, recommendations originating from NP, providing a ranking of food items exclusively based on nutrient contents, do not take into account the individual variability in response to food intake, which is related to behavioural and genetic heterogeneity among people. Particularly, from a genetic perspective, polymorphisms profoundly affect either genes encoding taste receptors or genes encoding a number of peripheral signalling peptides such as insulin, leptin, ghrelin, cholecystokinin and corresponding receptors [7].

Thus, shifting preventive strategies from population-based recommendations to personalized nutritional advice is perceived as a very attractive proposition [8]. Providing information on the possibility of developing complex conditions like obesity or diabetes before they develop may in fact motivate people to change their behaviour in order to reduce their future risk of developing these condition [9]. This possibility becomes practicable with the emergence of nutritional genomics and the availability of nutrigenetic tests which use genetic information to identify food products suited/not suited to the individual nutrigenetic profile $[10,11]$.

However, even if recently several kits for performing nutrigenomic analysis have been produced at industry level [12], to the authors' knowledge, no attempts have been made to better understand preventive and public health implications of the distribution of such instruments; in particular the agreement between information provided by nutrigenomic kits and recommendations traditionally based on NP schemes has never been evaluated.

Therefore, following an orientation, the purpose of the present study is to compare the personalized dietary recommendations provided by nutrigenetic assessment to a sample of 24 Italian children using a commercial nutrigenomic and nutrigenetic kit, the G-profile ${ }^{\circledR}$ test, with the recommendations based on 2 different, widely used NP schemes usually taken as references, and to calculate in particular genetic test-NP agreement regarding the suitability of 50 commonly eaten foods.

\section{Subjects and Methods}

Data Collection

Twelve normal-weight and 12 overweight children, matched by age and gender, were recruited in the Trieste district (North-East Italy), and nutrigenetic testing was offered to them using the G-Diet ${ }^{\circledR}$ Nutrigenomic Kit. The parents of all study participants signed a consent form; the data were kept anonymous. According to Italian regulations, no ethics committee approval is required for such studies. All participating families received feedback on the test, as agreed upon at the beginning of the study. 


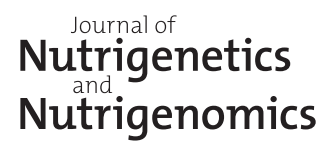

\begin{tabular}{l|l}
\hline J Nutrigenet Nutrigenomics 2011;4:25-35 \\
\hline $\begin{array}{l}\text { DOI: 10.1159/000322569 } \\
\text { Published online: March 23, 2011 }\end{array}$ & $\begin{array}{l}\text { @ 2011 S. Karger AG, Basel } \\
\text { www.karger.com/jnn }\end{array}$ \\
\hline
\end{tabular}

Published online: March 23, 2011 www.karger.com/jnn

Gregori et al.: Genetic Perspective on NP

\section{Nutrigenetic Assessment}

For nutrigenetic testing, the G-Diet Nutrigenomic Kit (http://www.gdiet.it), produced at the Area Science Park of Trieste (Italy), was used. The nutrigenetic test was provided by G\&Life Srl (Biella, Italy). Cheek cell samples were collected in the ZETA research laboratories (Trieste, Italy) using 2 buccal swabs, and the patient completed a comprehensive diet and lifestyle questionnaire. Variants of 20 genes were tested, particularly focusing on polymorphisms in genes (i) encoding taste [13, 14] (leptin taste receptor, type 2, member 38, or TAS2R38), (ii) linked to lactose tolerance [15] (lactases), (iii) involved in folate metabolism [16] (methylenetetrahydrofolate reductase or MTHFR), (iv) having a role in glycaemic control [17-20] (peroxisome proliferator-activated receptor- $\gamma$ coactivator $1 \alpha$ or PGC-1 $\alpha$, peroxisome proliferator-activated receptor- $\gamma$ or PPAR- $\gamma 2$, transcription factor 7-like 2 gene or TCF7L2, tumour necrosis factor- $\alpha$ or TNF- $\alpha$ ), (v) involved in fat metabolism [21, 22] [leptin receptors 1 and 2, ghrelin, PPAR- $\alpha$, low-density lipoprotein (LDL) receptor, resistin, $\beta_{1}$-adrenoceptor, $\beta_{3}$-adrenoceptor], (vi) regulating bone metabolism [23, 24] (ethylene response sensor 1 or ERS1, LDL receptor-related protein 5 or LRP5), and (vii) involved in lifestyle choices including smoking behaviour $[25,26]$ (angiotensin-converting enzyme or ACE, cholinergic receptor, nicotinic, alpha 3 or CHRNA3).

\section{NP Schemes}

Among the schemes proposed in the literature, we considered 2 of those most often used: the USA Health Claims (USAHC) scheme (FDA) [27] and the Guidelines for Responsible Food Marketing to Children, published by the US Center for Science in the Public Interest (CSPI) [28].

The USAHC scheme was defined by the FDA in the USA in 2002 [27] and was designed to identify products eligible for approved health claims. It is a threshold scheme which operates by considering whether or not a food has a nutrient content higher or lower than a specified cutoff. The FDA takes into account 10 nutrients considered as 'disqualifying' (total fat, saturated fatty acids or SFA, cholesterol and sodium) or 'qualifying' (vitamin A, vitamin C, iron, calcium, protein or fibre prior to any fortification). The reference amount is the serving size. The rationale for the threshold value is inspired by regulatory rules (daily values) based on nutritional recommendations and calculated for a 2,000-kcal diet. For fat, SFA, cholesterol and sodium the cutoff values correspond to $20 \%$ of the daily values; for vitamin A, vita$\min \mathrm{C}$, iron, calcium, protein and fibre the cutoff values correspond to $10 \%$ of the daily values. In order to carry a health claim, a food must meet the levels for all the disqualifying nutrients and for at least 1 of the qualifying nutrients by nature. The maximum amount allowed was $13 \mathrm{~g}$ total fat, $60 \mathrm{mg}$ cholesterol and $480 \mathrm{mg}$ sodium, all of them per serving size.

The CSPI scheme [28] aims to identify products that provide some nutritional benefit and that could help children meet the Dietary Guidelines for Americans. This threshold scheme is conceived to limit the intake of calories, SFA and trans-fatty acids, refined sugars and sodium in children. The criteria are based on the percentage of calories or amount per serving. Thresholds in energy percentages for fat, SFA and added sugars seem to correspond to American population goals [29], and most of the other thresholds correspond to meaningful levels in US regulations (nutrient content, portion size).

\section{Dietetic Assessment}

Dietetic indications were derived from the results of the nutrigenomic test by 2 medical doctors with specific training in genetics and nutritional science. The assessment was performed independently by the 2 doctors, who were asked to define as appropriate/inappropriate each of the food items considered by the 2 schemes on the basis of the results from nutrigenetic testing. The overall agreement between them in providing such dietetic indications was very high, reaching a Cohen's $\kappa$ of 0.87 .

\section{Statistical Analysis}

For continuous variables, the data are presented as medians and 1st to 3rd quartiles as a measure of dispersion, and as percentages and absolute numbers for categorical variables. Groups were compared using Wilcoxon tests for continuous variables and Fisher's $\chi^{2}$ test for categorical variables. Agreement between the NP schemes and among the nutrigenomic indications and both profiles was computed using Cohen's $\kappa$, and $p$ values were assessed using the $z$-score method [30]. $p$ was considered significant at the 0.05 level. All analyses were performed using System R. 


\section{Nutriga of \\ Nutrigenomics}

\begin{tabular}{l|l}
\hline J Nutrigenet Nutrigenomics 2011;4:25-35 \\
\hline $\begin{array}{l}\text { DOl: 10.1159/000322569 } \\
\text { Published online: March 23, 2011 }\end{array}$ & $\begin{array}{l}\text { O 2011 S. Karger AG, Basel } \\
\text { www.karger.com/jnn }\end{array}$ \\
\hline Gregori et al.: Genetic Perspective on NP &
\end{tabular}
www.karger.com/jnn

Table 1. Description of the sample

\begin{tabular}{|c|c|c|c|c|c|}
\hline & $\mathrm{N}$ & $\begin{array}{l}\text { Normal weight } \\
(\mathrm{n}=12)\end{array}$ & $\begin{array}{l}\text { Overweight/obese } \\
(\mathrm{n}=12)\end{array}$ & $\begin{array}{l}\text { Combined } \\
(\mathrm{n}=24)\end{array}$ & $\mathrm{p}$ \\
\hline Gender - male & 24 & $50 \%(6)$ & $50 \%(6)$ & $50 \%(12)$ & - \\
\hline Age, years & 24 & $4.75 / 8.00 / 11.00$ & $5.75 / 6.50 / 11.00$ & $5.00 / 7.00 / 11.00$ & 0.931 \\
\hline BMI & 24 & $15.7250 / 16.2500 / 17.0925$ & $19.5675 / 21.1000 / 21.7450$ & $16.2750 / 18.1700 / 20.9500$ & $<0.001^{*}$ \\
\hline Mother's height, $\mathrm{cm}$ & 24 & $168.75 / 170.00 / 170.00$ & $162.25 / 167.00 / 170.00$ & $164.75 / 169.50 / 170.00$ & 0.144 \\
\hline Mother's weight, kg & 24 & $57.25 / 62.50 / 70.50$ & $54.75 / 62.50 / 72.00$ & $55.00 / 62.50 / 72.00$ & 0.844 \\
\hline Mother's exercise, $\mathrm{h}$ /week & 24 & $0 / 0 / 0$ & $0 / 0 / 0$ & $0 / 0 / 0$ & 0.494 \\
\hline Father's height, $\mathrm{cm}$ & 24 & $175.75 / 177.00 / 180.50$ & $180.00 / 183.00 / 192.25$ & $176.00 / 180.00 / 185.50$ & $0.012^{*}$ \\
\hline Father's weight, kg & 24 & $69.50 / 72.00 / 74.25$ & $91.25 / 98.50 / 110.00$ & $72.00 / 78.50 / 96.75$ & $<0.001^{*}$ \\
\hline Father's exercise, h/week & 24 & $0.0 / 3.5 / 7.0$ & $0.0 / 0.0 / 0.5$ & $0.0 / 0.0 / 4.5$ & $0.039^{*}$ \\
\hline Hunger - fair/good & 24 & $42 \%(5)$ & $17 \%(2)$ & $29 \%(7)$ & 0.178 \\
\hline Meals with family, $\mathrm{n} /$ week & 24 & $9.00 / 10.50 / 14.50$ & $10.75 / 12.00 / 16.00$ & $10.00 / 11.00 / 16.00$ & 0.328 \\
\hline Meals/day & 24 & $5.000 / 5.000 / 5.000$ & $4.000 / 5.000 / 5.000$ & $4.875 / 5.000 / 5.000$ & 0.448 \\
\hline $\mathrm{TV} / \mathrm{PC} /$ videogames & 24 & & & & 0.274 \\
\hline$<2 \mathrm{~h} /$ day & & $92 \%(11)$ & $58 \%(7)$ & $75 \%(18)$ & \\
\hline$<3$ h/day & & $0 \%(0)$ & $8 \%(1)$ & $4 \%(1)$ & \\
\hline$>4$ h/day & & $0 \%(0)$ & $8 \%(1)$ & $4 \%(1)$ & \\
\hline $2-4 \mathrm{~h} /$ day & & $8 \%(1)$ & $25 \%(3)$ & $17 \%(4)$ & \\
\hline \multicolumn{3}{|c|}{ Physical activity outside school 23} & & & 0.726 \\
\hline 1/week & & $17 \%(2)$ & $18 \%(2)$ & $17 \%(4)$ & \\
\hline $2-3 /$ week & & $42 \%(5)$ & $55 \%(6)$ & $48 \%(11)$ & \\
\hline 4-6/week & & $8 \%(1)$ & $9 \%(1)$ & $9 \%(2)$ & \\
\hline Never & & $17 \%(2)$ & $18 \%(2)$ & $17 \%(4)$ & \\
\hline Every day & & $17 \%(2)$ & $0 \%(0)$ & $9 \%(2)$ & \\
\hline \multicolumn{3}{|c|}{ Physical activity outside school 24} & & & 0.979 \\
\hline$\geq 7 \mathrm{~h} /$ week & & $8 \%(1)$ & $8 \%(1)$ & $8 \%(2)$ & \\
\hline $0 \mathrm{~h} /$ week & & $17 \%(2)$ & $8 \%(1)$ & $12 \%(3)$ & \\
\hline $1 \mathrm{~h} /$ week & & $17 \%(2)$ & $17 \%(2)$ & $17 \%(4)$ & \\
\hline $2-3 \mathrm{~h} /$ week & & $25 \%(3)$ & $25 \%(3)$ & $25 \%(6)$ & \\
\hline $4-6 \mathrm{~h} /$ week & & $33 \%(4)$ & $42 \%(5)$ & $38 \%(9)$ & \\
\hline
\end{tabular}

Continuous variables are shown as 1st quartile/median/3rd quartile, and categorical variables as percentage with absolute number in parentheses. $\mathrm{N}=$ Number of cases with valid information. ${ }^{*}$ p significant at 0.05 level.

\section{Results}

The sample is described in table 1 . The only association with overweight condition is found with father's height and father's weight, with a p value of 0.012 and $<0.001$, respectively. No association is seen with other variables like level of hunger, the number of meals per day, regular breakfasts in a week, the consumption of fruits, vegetables, chocolate or snacks, the length of use of TV, PC or videogames, and the duration, when present, of physical activity outside school.

Individual results of the nutrigenomic analysis of the sample are shown in table 2 . The nutritional indications, coming from the profiles and the nutrigenomic analysis, are provided for each individual in table 3 and seem to be noticeably dissimilar. Agreement between the USAHC and CSPI schemes, as assessed by Cohen's $\kappa$, is very poor overall (0.66), tending to be lower for cereals (0.48), milk and cheese (0.50) and drinks (0.57), and only slightly higher for bread and bakery products $(0.85)$. The agreement between the nutrigenomic indications and both profiles is provided at the bottom of table 3 . The agreement overall ranges 


\section{Nutrigenetics \\ Nutrigenomics}

Table 2. Individual results of the nutrigenomic analysis of the sample

苟

Normal weight

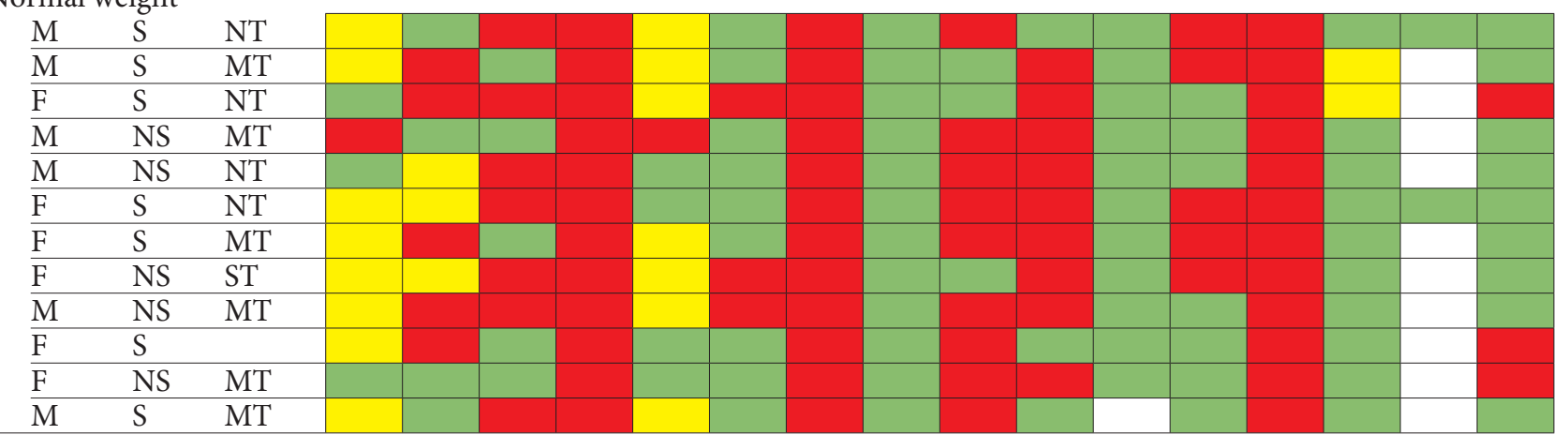

Overweight/obese

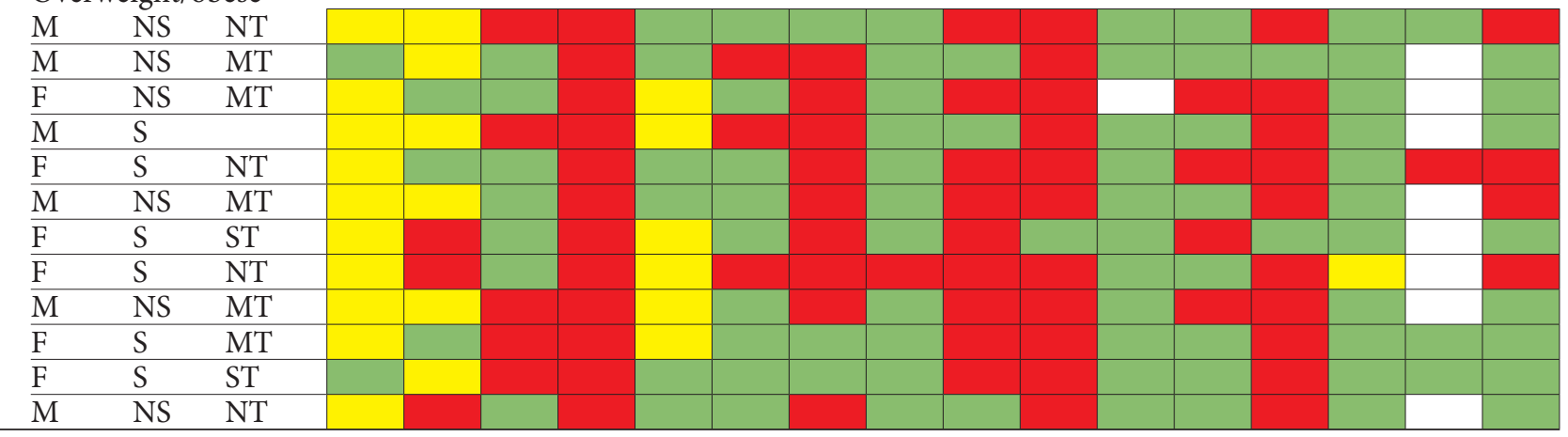

Data on age, BMI and percentiles of BMI have been omitted. Green: most favourable set. Red: less favourable set. Yellow: intermediate scenario. $\mathrm{M}=$ Male; $\mathrm{F}$ = female; $\mathrm{S}=$ sensitive; $\mathrm{NS}=$ nonsensitive; $\mathrm{MT}$ = medium taster; $\mathrm{ST}=$ supertaster; $\mathrm{NT}=$ nontaster.

from 0.43 to 0.74 for each nutrigenomic profile with the USAHC profiling system, and from 0.29 to 0.80 with the CSPI scheme. Notice that this is basically replicated both for the overweight/obese and the normal groups (0.43-0.72 and 0.43-0.74, respectively, for USAHC scheme; $0.29-0.71$ and $0.29-0.80$, respectively, for the CSPI scheme).

\section{Discussion}

During the last decade, with an increased emphasis on food contribution to health, NP research has been developed as a method of ranking the healthiness of foods, and several NP schemes have been proposed in order to improve the diet of the population by assisting consumer choices. However, significant differences in food classification seem to exist among different profiling schemes. In the present study, we calculated the agreement between two of 


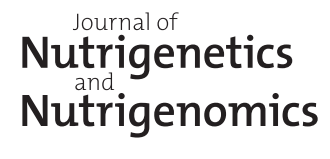

J Nutrigenet Nutrigenomics 2011;4:25-35

\begin{tabular}{|l|l|l}
\hline DOI: $10.1159 / 000322569$ & @ 2011 S. Karger AG, Basel
\end{tabular}

Published online: March 23, 2011

www.karger.com/jnn

30

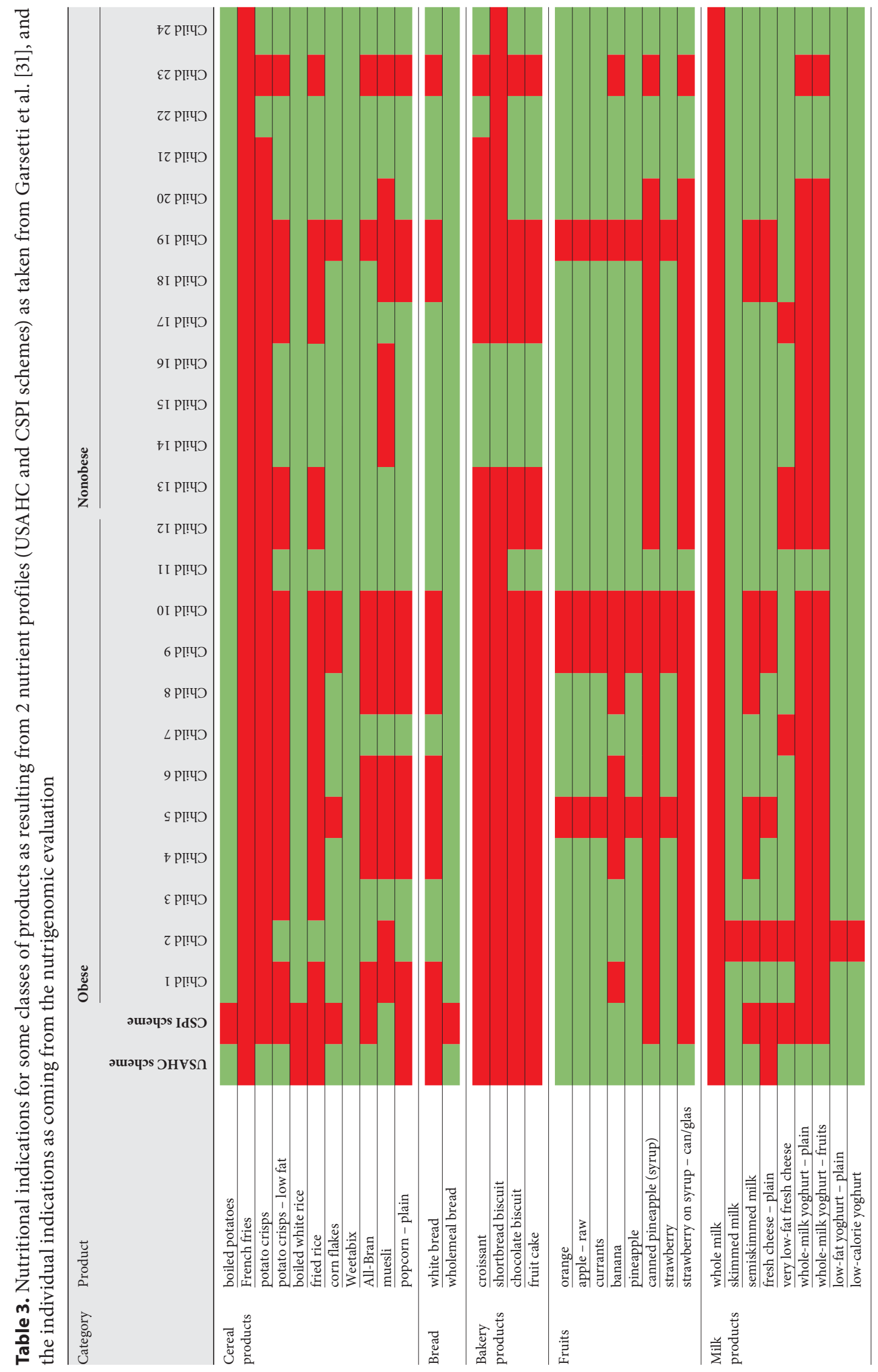




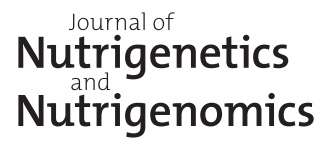

J Nutrigenet Nutrigenomics 2011;4:25-35

\begin{tabular}{|l|l|}
\hline DOI: $10.1159 / 000322569$ & ๑) 2011 S. Karger AG, Basel
\end{tabular}

Published online: March 23, 2011

www.karger.com/jnn

Gregori et al.: Genetic Perspective on NP

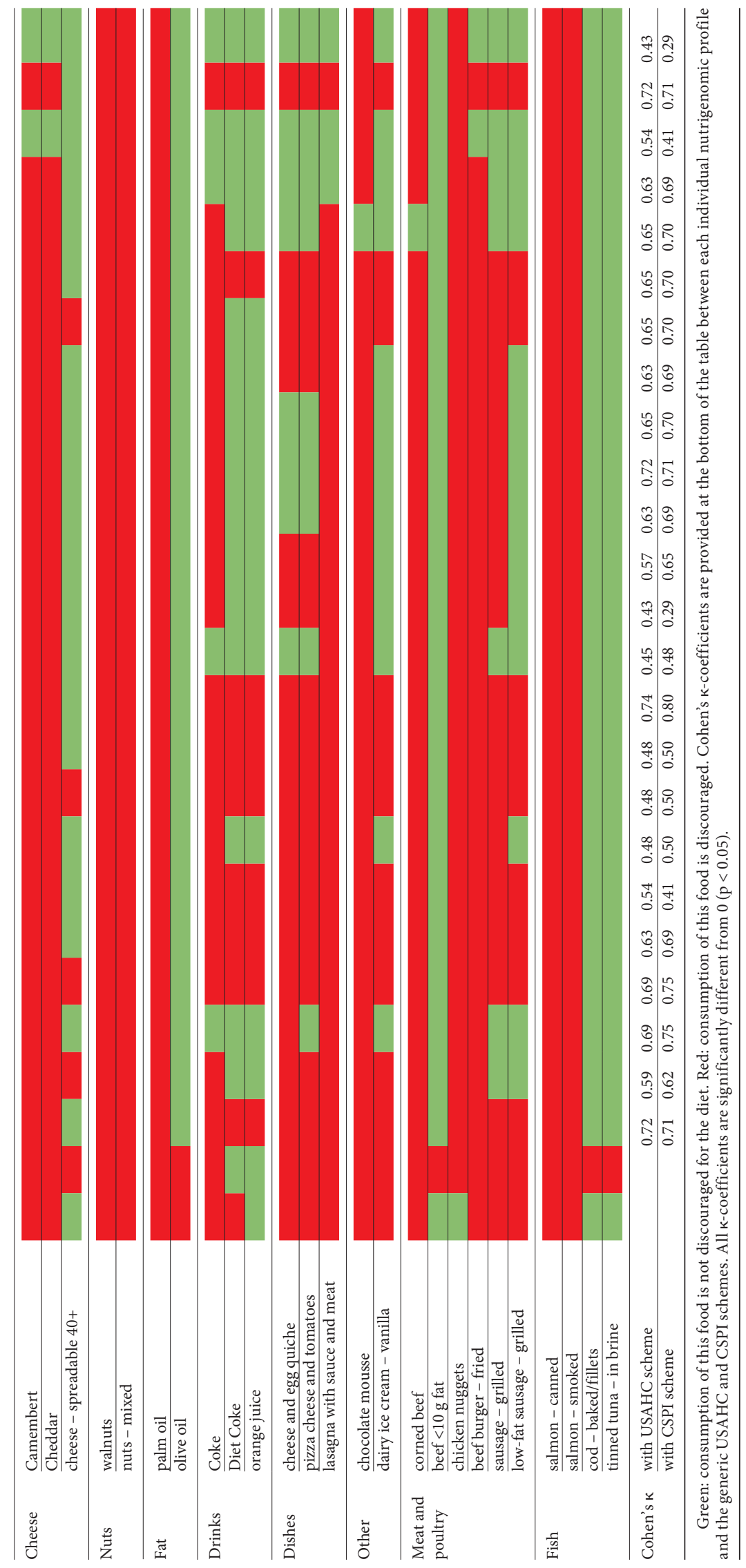


such schemes (table 3). For almost half the selected food products, the results were inconsistent, as was previously pointed out by Garsetti et al. [31]. This clearly is an unsatisfactory performance of the profiling schemes and perhaps of the entire food profiling machinery: they do not only fail to consider the heterogeneity of individual response, assuming that all persons have average dietary requirements, but they also widely disagree on very basic foods, some being critical components of dietary schemes, e.g. bread or pasta for the 'Mediterranean diet'.

On the other hand, science is beginning to understand how genetic variation and epigenetic events alter requirements and responses to nutrients, therefore developing methods for nutrigenetic profiling [32]. In fact, since the complete sequencing of the human genome, important polymorphic sites (single-nucleotide polymorphisms or SNPs) which dictate individual phenotypic differences among the population have been mapped within the genome; it is already apparent that SNP analysis provides a powerful molecular tool for investigating the role of nutrition in human health and disease, and their consideration in clinical, metabolic and epidemiological studies can contribute enormously to the definition of optimal diets [33].

A well-known and studied example is the 677 C3T polymorphism in the 5,10-MTHFR $($ MTHFR $677 \mathrm{C} \rightarrow \mathrm{T}$ ). People carrying the MTHFR $677 \mathrm{C} \rightarrow \mathrm{T}$ allele, which lowers the conversion of homocysteine to methionine, require more folate and B vitamins in their diet in order to keep homocysteine levels low [34]. Since homocysteine is considered a cardiovascular risk factor, dietary supplementation with folate has been proposed as a preventive measure to lower the risk of cardiovascular disease $[35,36]$.

In order to predict the overall effect of different polymorphisms, genes that are principally involved in the metabolism and transport of nutrients, removal of toxins and protection from oxidation are usually assessed by nutrigenomic tests, leading to the identification of specific genetic patterns [10]. According to the particular pattern of genetic variation, personalized advice can be generated; these tests provide recommendations on dietary and lifestyle modifications to attain specific goals in nutrition and exercise, and to optimize the nutrient content of an individual's daily food intake, based on current understanding of an individual's genetic profile [10]. Indeed, several commercial products have started to emerge and are proposed as quick checks to get personalized advice on more appropriate dieting based on genetic profiles.

When personalized dietary advice provided by nutrigenetic assessment is compared with NP recommendations, as done in this article, results can be surprising: agreement in our analysis was generally poor, and in some cases lower than $30 \%$. These results underline the abovementioned inability of the traditional NP approach to take into account individual peculiarities, ending up in inappropriately targeted dietary recommendations. In contrast, genetic profiles are usually considered as a way to identify an individual risk profile, suggesting specific lifestyle changes to reduce the risk of frequent pathologies such as heart disease, diabetes and obesity [37].

However, it must be noted that many of the nutrigenomic tests are based on information generated from publicly and privately funded research which has identified gene-diet and gene-nutrient interactions and may have important health implications, but they have not yet been clinically validated. In fact, as argued by Haga et al. [37], although genomic profiling seems to be useful in identifying tailored preventive strategies, the science is still in its early stage of understanding gene-gene and gene-environment interactions and their health implications. Recently, Janssens et al. [38] assessed the scientific evidence supporting the purported gene-disease associations for genes included in genomic profiles by examining previous metaanalyses. Of the 56 genes tested by 7 different companies offering predictive genomic profiling, 24 (43\%) had not been reviewed in metaanalyses. For the remaining 32 genes, these authors found 260 metaanalyses that examined 160 unique polymorphism-dis- 
ease associations, of which only 60 (38\%) were found to be statistically significant. Even the 60 significant associations, which involved 29 different polymorphisms and 28 different diseases, were generally modest, with synthetic odds ratios ranging from 0.54 to 0.88 for protective variants and from 1.04 to 3.2 for risk variants.

In addition, what is very clear at this point is that only in very rare instances is a single SNP associated with a specific health state; rather there is increasing evidence that a given aberrant health state is almost always associated with multiple SNPs that interact in ways not yet understood. However, the current commercial opportunity for nutrigenetics has taken the form of nutrigenetic testing kits on the market that focus on a limited number of specific health states and specific genes. Without standards and oversight, it is difficult to assess their reliability and to evaluate them [38]; therefore, in the present study, no comparisons with other kits have been carried out.

Finally, even when a gene-disease association is well characterized, there still is no evidence that nutritional changes based on the recommendations from individualized analyses may reduce an individual's risk of developing a particular disease, as happens regarding the above-cited MTHFR $677 \mathrm{C} \rightarrow \mathrm{T}$ polymorphism [39], for which present recommendations about folate intake based on genotype are contrasting [40].

Since the aim of this study was to assess in the most realistic way the performances of such tests, results from the nutrigenomic kits have been taken 'as is', i.e. without including new insights about specific genotype characteristics or genetic relationships, relying only on the standard indications derived from the kits.

Thus, while disagreement on food classification among different NP schemes seems to advocate more research into the classical NP approach, indications derived from nutrigenetics, even if appealing, cannot yet be used as a reference, given the fact that scientific evidence supporting genomic profiling is inconsistent and data on health outcome benefits based on such testing are lacking [37]. Despite advances in nutrition and nutrigenomics, much more research in this field seems, in fact, to be required [41].

From a public health perspective the question could now be where more effort should be invested: whether to insist on generic, traditional ways of profiling nutrients or to invest in more advanced, individually targeted nutrient genomic and genetic information. While traditional nutrient profiles are unable to cope with individual heterogeneity, nutrigenomic and nutrigenetic profiles have, perhaps, a long way to go before becoming a gold standard, but at least in principle - they do not share the limitations of the traditional approaches.

Since scientific evidence is supposed to be the cornerstone of preventive public health strategies, clinical benefits resulting from any nutritional intervention, including those derived from NP suggestions and those based on genotyping, should be proved and inserted in a risk management framework relating nutrients with their impact on health. Observational studies and clinical trials with well-defined long-term end points, particularly targeting their effectiveness at a population level, should thus be the next step in evaluating the most advanced nutrigenomic and nutrigenetic techniques in profiling nutrients.

\section{References}

1 Komduur RH, Korthals M, te Molder H: The good life: living for health and a life without risks? On a prominent script of nutrigenomics. Br J Nutr 2009;101:307-316.

2 Han JC, Lawlor DA, Kimm SY: Childhood obesity. Lancet 2010;375:1737-1748.

3 Visioli F, Poli A, Peracino A, Luzi L, Cannella C, Paoletti R: Assessment of nutritional profiles: a novel system based on a comprehensive approach. Br J Nutr 2007;98:1101-1107.

4 Rayner M, Scarborough P, Williams C: The origin of Guideline Daily Amount and the Food Standard Agency's guidance on what counts as 'a lot' and 'a little'. Public Health Nutr 2004;7:549-556. 


\section{Nutrigenetics \\ Nutrigenomics}

\begin{tabular}{l|l}
\hline J Nutrigenet Nutrigenomics 2011;4:25-35 \\
\hline DOI: 10.1159/000322569 & $\begin{array}{l}\text { @ 2011 S. Karger AG, Basel } \\
\text { www.karger.com/jnn }\end{array}$ \\
Published online: March 23, 2011 &
\end{tabular}

Gregori et al.: Genetic Perspective on NP

5 Food Standards Agency: Scientific workshop to assess the Food Standards Agency's proposed approach to nutrient profiling. 2005. http://www.food.gov.uk/multimedia/pdfs/nutprofworkshop250205.pdf.

6 Drewnowski A, Maillot M, Darmon N: Should nutrient profiles be based on 100 g, 100 kcal or serving size? Eur J Clin Nutr 2009;63:898-904.

7 Loktionov A: Common gene polymorphisms and nutrition: emerging links with pathogenesis of multifactorial chronic diseases. J Nutr Biochem 2003;14:426-451.

8 Müller M, Kersten S: Nutrigenomics: goals and strategies. Nat Rev Genet 2003;4:315-322.

-9 Sanderson SC, Wardle J, Humphries SE: Public health genomics and genetic test evaluation: the challenge of conducting behavioural research on the utility of lifestyle-genetic tests. J Nutrigenet Nutrigenomics 2008;1:224-231.

10 Arkadianos I, Valdes AM, Marinos E, Florou A, Gill RD, Grimaldi KA: Improved weight management using genetic information to personalize a calorie controlled diet. Nutr J 2007;6:29.

11 Marteau TM, Lerman C: Genetic risk and behavioural change. BMJ 2001;322:1056-1059.

12 Roses AD: Pharmacogenetics and the practice of medicine. Nature 2000;405:857-865.

13 Mizuta E, Kokubo Y, Yamanaka I, Miyamoto Y, Okayama A, Yoshimasa Y, Tomoike H, Morisaki H, Morisaki T: Leptin gene and leptin receptor gene polymorphisms are associated with sweet preference and obesity. Hypertens Res 2008; 31:1069-1077.

14 El-Sohemy A, Stewart L, Khataan N, Fontaine-Bisson B, Kwong P, Ozsungur S, Cornelis MC: Nutrigenomics of taste: impact on food preferences and food production. Forum Nutr 2007;60:176-182.

15 Ingram CJ, Mulcare CA, Itan Y, Thomas MG, Swallow DM: Lactose digestion and the evolutionary genetics of lactase persistence. Hum Genet 2009;124:579-591.

16 Messika AH, Kaluski DN, Lev E, Iakobishvili Z, Shohat M, Hasdai D, Mager A: Nutrigenetic impact of daily folate intake on plasma homocysteine and folate levels in patients with different methylenetetrahydrofolate reductase genotypes. Eur J Cardiovasc Prev Rehabil 2010, E-pub ahead of print.

17 Vimaleswaran KS, Radha V, Ghosh S, Majumder PP, Deepa R, Babu HN, Rao MR, Mohan V: Peroxisome proliferatoractivated receptor- $\gamma$ co-activator- $1 \alpha$ (PGC- $1 \alpha)$ gene polymorphisms and their relationship to type 2 diabetes in Asian Indians. Diabet Med 2005;22:1516-1521.

- 18 Ereqat S, Nasereddin A, Azmi K, Abdeen Z, Amin R: Impact of the Pro12Ala polymorphism of the PPAR- $\gamma 2$ gene on metabolic and clinical characteristics in the Palestinian type 2 diabetic patients. PPAR Res 2009;2009:874126.

19 Ereqat S, Nasereddin A, Cauchi S, Azmi K, Abdeen Z, Amin R: Association of a common variant in TCF7L2 gene with type 2 diabetes mellitus in the Palestinian population. Acta Diabetol 2009, E-pub ahead of print.

20 Stefanyk LE, Dyck DJ: The interaction between adipokines, diet and exercise on muscle insulin sensitivity. Curr Opin Clin Nutr Metab Care 2010;13:255-259.

21 Kursawe R, Narayan D, Cali AM, Shaw M, Pierpont B, Shulman GI, Caprio S: Downregulation of ADIPOQ and PPAR 2 gene expression in subcutaneous adipose tissue of obese adolescents with hepatic steatosis. Obesity (Silver Spring) 2010;18:1911-1917.

22 Majumdar ID, Weber HC: Gastrointestinal regulatory peptides and their effects on fat tissue. Curr Opin Endocrinol Diabetes Obes 2010;17:51-56.

23 Kjaergaard AD, Ellervik C, Tybjaerg-Hansen A, Axelsson CK, Grønholdt ML, Grande P, Jensen GB, Nordestgaard BG: Estrogen receptor- $\alpha$ polymorphism and risk of cardiovascular disease, cancer, and hip fracture: cross-sectional, cohort, and case-control studies and a meta-analysis. Circulation 2007;115:861-871.

24 Yadav VK, Ducy P: Lrp5 and bone formation: a serotonin-dependent pathway. Ann NY Acad Sci 2010;1192:103-109.

-25 Arias-Vásquez A, Sayed-Tabatabaei FA, Schut AF, Hofman A, Bertolli-Avella AM, Vergeer JM, Aulchenko YS, Witteman JC, van Duijn CM: Angiotensin-converting enzyme gene, smoking and mortality in a population-based study. Eur J Clin Invest 2005;35:444-449.

-26 Freathy RM, Ring SM, Shields B, Galobardes B, Knight B, Weedon MN, Smith GD, Frayling TM, Hattersley AT: A common genetic variant in the $15 \mathrm{q} 24$ nicotinic acetylcholine receptor gene cluster (CHRNA5-CHRNA3-CHRNB4) is associated with a reduced ability of women to quit smoking in pregnancy. Hum Mol Genet 2009;18:2922-2927.

27 Williams C, Rayner M, Myatt M, Boaz A: Use your label: making sense of nutrition information. Food sense leaflet. London, Ministry of Agriculture Fisheries and Food, 1996.

28 Center for Science in the Public Interest: Guidelines for responsible food marketing to children. Washington, Center for Science in the Public Interest, 2005.

29 Food and Nutrition Board Institute of Medicine: Dietary reference intakes for energy, carbohydrate, fiber, fat, fatty acids, cholesterol, protein, and amino acids. Washington, National Academies Press, 2002.

30 Cohen J: A coefficient of agreement for nominal scales. Educ Psychol Meas 1960;20:37-46.

-31 Garsetti M, de Vries J, Smith M, Amosse A, Rolf-Pedersen N: Nutrient profiling schemes: overview and comparative analysis. Eur J Nutr 2007;46(suppl 2):15-28.

-32 Zeisel SH: Nutrigenomics and metabolomics will change clinical nutrition and public health practice: insights from studies on dietary requirements for choline. Am J Clin Nutr 2007;86:542-548.

-33 Ames BN: Cancer prevention and diet: help from single nucleotide polymorphisms. Proc Natl Acad Sci USA 1999;96: 12216-12218.

- 34 Papoutsakis C, Manios Y, Magkos F, Papaconstantinou E, Schulpis KH, Zampelas A, Matalas AL, Yiannakouris N: Effect of the methylenetetrahydrofolate reductase (MTHFR $677 \mathrm{C} \rightarrow \mathrm{T}$ ) polymorphism on plasma homocysteine concentrations in healthy children is influenced by consumption of folate-fortified foods. Nutrition 2010;26:969974 . 


\section{Journal of \\ Nutrigenetics \\ Nutrigenomics}

J Nutrigenet Nutrigenomics 2011;4:25-35

\begin{tabular}{l|l}
\hline DOI: $10.1159 / 000322569$ & $\begin{array}{l}\text { C 2011 S. Karger AG, Basel } \\
\text { www.karger.com/jnn }\end{array}$ \\
\hline Published online: March 23, 2011 & \\
\hline
\end{tabular}

Gregori et al.: Genetic Perspective on NP

- 35 Selhub J, Jacques PF, Bostom AG, D’Agostino RB, Wilson PW, Belanger AJ, O’Leary DH, Wolf PA, Schaefer EJ, Rosenberg IH: Association between plasma homocysteine concentrations and extracranial carotid-artery stenosis. N Engl J Med 1995;332:286-291.

- 36 Meshkin B, Blum K: Folate nutrigenetics: a convergence of dietary folate metabolism, folic acid supplementation, and folate antagonist pharmacogenetics. Drug Metab Lett 2007;1:55-60.

- 37 Haga SB, Khoury MJ, Burke W: Genomic profiling to promote a healthy lifestyle: not ready for prime time. Nat Genet 2003;34:347-350.

- 38 Janssens AC, Gwinn M, Bradley LA, Oostra BA, van Duijn CM, Khoury MJ: A critical appraisal of the scientific basis of commercial genomic profiles used to assess health risks and personalize health interventions. Am J Hum Genet 2008;82:593-599.

-39 Ashfield-Watt PA, Pullin CH, Whiting JM, Clark ZE, Moat SJ, Newcombe RG, Burr ML, Lewis MJ, Powers HJ, McDowell IF: Methylenetetrahydrofolate reductase $677 \mathrm{C} \rightarrow$ T genotype modulates homocysteine responses to a folaterich diet or a low-dose folic acid supplement: a randomized controlled trial. Am J Clin Nutr 2002;76:180-186.

-40 Bazzano LA, Reynolds K, Holder KN, He J: Effect of folic acid supplementation on risk of cardiovascular diseases: a meta-analysis of randomized controlled trials. JAMA 2006;296:2720-2726.

-41 de Vrieze J, Bouwman L, Komduur R, Pin R, Ronteltap A, Vandeberg R, van Dam F, Penders B: Nutrition tailored to the individual? Not just yet - realigning nutrigenomic science with contemporary society. J Nutrigenet Nutrigenomics 2009;2:184-188.

\section{Erratum}

In the Abstract P038, 'The effect of the 4G/5G polymorphism on PAI-1act in a black South African population', published in vol. 3, issue 2-3, 2010 on p. 85 of 'Abstracts of the 4th Congress of the International Society of Nutrigenetics/Nutrigenomics', not all the authors were listed. The complete list and affiliations are as below:

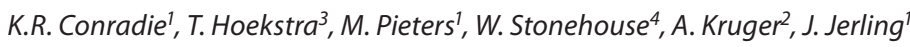

${ }^{1}$ Centre of Excellence for Nutrition, and ${ }^{2}$ Africa Unit for Transdisciplinary Health Research, North-West University, Potchefstroom, South Africa; ${ }^{3}$ University Medical Center, Utrecht, The Netherlands; ${ }^{4}$ Massey University,

Auckland, New Zealand 